\title{
Highlight report: critical evaluation of key evidence on health hazards of the general European population by exposure to arsenic
}

\author{
H. M. Bolt ${ }^{1}$
}

Published online: 24 November 2015

(C) Springer-Verlag Berlin Heidelberg 2015

In this issue, Ursula Gundert-Remy and colleagues contribute a review article about the need for risk reduction due to high exposure to inorganic arsenic in the general European population (Gundert-Remy et al. 2015; this issue). It is known since long that one of the largest manmade catastrophes was caused by drinking water contaminated with arsenic (Gundert-Remy et al. 2015; Golka et al. 2010; Ahmad 2001; Bae et al. 2002). In the 1970s, a WHO-initiated campaign in Bangladesh installed more than 4 million wells to reduce diseases due to microbiologically contaminated water (Gundert-Remy et al. 2015). However, contamination of this water with geogenic arsenic led to a situation, where more than 50 million people in Bangladesh were put at risk of arsenic-induced diseases (Golka et al. 2010; Gundert-Remy et al. 2015). However, the current review of Gundert-Remy and colleagues demonstrates that the exposure to arsenic is critical not only in countries of the third world but also in Europe. Arsenic is a carcinogen that induces tumors of the lung, urinary bladder, skin and kidney (IARC 1973, 1980, 2004, 2012; Francesconi 2010; Tokar et al. 2010; Wang et al. 2014; WHO 2011a, b, c; Zhou et al. 2014; Masoudi and Saadat 2008; Selinski 2012; Stewart and Marchan 2012). A recently published study of the EFSA on dietary exposure to inorganic arsenic demonstrates that mean dietary exposure of infants ranges between 0.2 and $1.37 \mu \mathrm{g} / \mathrm{kg}$ body weight per day (EFSA Journal 2014). On the other hand, benchmark doses resulting in a $1 \%$

\section{H. M. Bolt}

bolt@ifado.de

IfADo - Leibniz Research Centre for Working Environment and Human Factors, Ardeystr. 67, 44139 Dortmund, Germany increased risk of lung cancer were calculated to range between 0.3 and $8 \mu \mathrm{g} / \mathrm{kg}$ body weight/day (EFSA CONTAM Panel 2009; WHO 2011a; review: Gundert-Remy et al. 2015). This scenario illustrates that the margin of exposure is small or even absent-a situation that calls for urgent regulatory action to reduce arsenic exposure of the general European population (Gundert-Remy et al. 2015). The authors of the review article also explain why onesided regulatory measures to reduce arsenic only in rice are not sufficient. Priority measures should rather be to reduce arsenic in food categories that contribute most to exposure in Europeans, such as milk and dairy products, drinking water, and food for infants. Toxicity of arsenic represents a cutting-edge topic in our journal (Bolt 2012, 2013; Sinha et al. 2013; Kumasaka et al. 2013). Intensively_but sometimes also controversially-discussed are the carcinogenic effects, mechanisms and doseresponse relationships of arsenic (Waalkes et al. 2014a, b; Cohen et al. 2014; Xu et al. 2014; Méndez-Fernández et al. 2015; Bach et al. 2014). A particular research focus is how arsenic influences signaling pathways relevant in cell stress response and carcinogenesis (Chen et al. 2014; Wang et al. 2014; Weng et al. 2014; Liu et al. 2013; Jiang et al. 2013; Pastoret et al. 2013). Recently, also epigenetic alterations (Gribble et al. 2014), developmental toxicity (Zimmer et al. 2014; Stern et al. 2014) and metabolism as well as transport of arsenic (Tokar et al. 2014; Yu et al. 2013; Xu et al. 2013; Watanabe and Hirano 2013) have been intensively studied. The present review of GundertRemy and colleagues which comprehensively compares arsenic exposure likely to cause adverse effects in humans to current exposure levels of the general European population demonstrates that research of arsenic is of high practical relevance and should lead to regulatory action to reduce the risk of the general population. 


\section{References}

Ahmad K (2001) Report highlights widespread arsenic contamination in Bangladesh. Lancet 358:133

Bach J, Sampayo-Reyes A, Marcos R, Hernández A (2014) Ogg1 genetic background determines the genotoxic potential of environmentally relevant arsenic exposures. Arch Toxicol 88(3):585596. doi:10.1007/s00204-013-1151-0

Bae M, Watanabe C, Inaoka T, Sekiyama M, Sudo N, Bokul MH, Ohtsuka R (2002) Arsenic in cooked rice in Bangladesh. Lancet 360(9348):1839-1840. Erratum in: Lancet. 2002 Mar 22;361(9362): 1060

Bolt HM (2012) Arsenic: an ancient toxicant of continuous public health impact, from Iceman Ötzi until now. Arch Toxicol 86(6):825-830. doi:10.1007/s00204-012-0866-7 (Review)

Bolt HM (2013) Current research trends on arsenic toxicology. Arch Toxicol 87(6):925-926. doi:10.1007/s00204-013-1073-x

Chen YJ, Lai KC, Kuo HH, Chow LP, Yih LH, Lee TC (2014) HSP70 colocalizes with PLK1 at the centrosome and disturbs spindle dynamics in cells arrested in mitosis by arsenic trioxide. Arch Toxicol 88(9):1711-1723. doi:10.1007/s00204-014-1222-x

Cohen SM, Arnold LL, Klaunig JE, Goodman JI (2014) Re: Waalkes et al.: Lung tumors in mice induced by "whole-life" inorganic arsenic exposure at human-relevant doses, Arch Toxicol, 2014. Arch Toxicol 88(11):2061-2062. doi:10.1007/s00204-014-1328-1

EFSA (2014) Dietary exposure to inorganic arsenic in the European population. EFSA J 12(3):3597. doi:10.2903/j.efsa.2014.3597

EFSA Contam Panel (EFSA Panel on Contaminants in the Food Chain) (2009) Scientific opinion on arsenic in food. EFSA J 7(10): 1351

Francesconi KA (2010) Arsenic species in seafood: origin and human health implications. Pure Appl Chem 82(2):373-381

Golka K, Hengstler JG, Marchan R, Bolt HM (2010) Severe arsenic poisoning: one of the largest man-made catastrophies. Arch Toxicol 84(8):583-584. doi:10.1007/s00204-010-0575-Z

Gribble MO, Tang WY, Shang Y, Pollak J, Umans JG, Francesconi KA, Goessler W, Silbergeld EK, Guallar E, Cole SA, Fallin MD, Navas-Acien A (2014) Differential methylation of the arsenic (III) methyltransferase promoter according to arsenic exposure. Arch Toxicol 88(2):275-282. doi:10.1007/ s00204-013-1146-x

Gundert-Remy U, Damm G, Foth H, Freyberger A, Gebel T, Golka K, Röhl C, Schupp T, Wollin K-M, Hengstler JG (2015) High exposure to inorganic arsenic by food: the need for risk reduction. Arch Toxicol 89(12). doi:10.1007/s00204-015-1627-1

IARC (International Agency for Research on Cancer) (1973) Arsenic and inorganic arsenic compounds. In: Some inorganic and organometallic compounds. IARC monographs on the evaluation of carcinogenic risk of chemicals to humans, vol 2. Lyon, France: International Agency for Research on Cancer, pp 48-73

IARC (International Agency for Research on Cancer) (1980) Arsenic and arsenic compounds. In: Some metals and metallic compounds. IARC monographs on the evaluation of carcinogenic risk of chemicals to humans, vol 23. Lyon, France: International Agency for Research on Cancer, pp 39-141

IARC (International Agency for Research on Cancer) (2004) Arsenic and arsenic compounds. In: Some drinking water disinfectants and contaminants, including arsenic, IARC monographs on the evaluation of carcinogenic risk of chemicals to humans, vol 84 , $39-270$

IARC (International Agency for Research on Cancer) (2012) Arsenic and arsenic compounds. In: Arsenic, metals, fibres and dusts, IARC monographs on the evaluation of carcinogenic risk of chemicals to humans, 100C, pp 41-94
Jiang R, Li Y, Xu Y, Zhou Y, Pang Y, Shen L, Zhao Y, Zhang J, Zhou J, Wang X, Liu Q (2013) EMT and CSC-like properties mediated by the IKK $\beta / \mathrm{I} \kappa \mathrm{B} \alpha /$ RelA signal pathway via the transcriptional regulator, Snail, are involved in the arsenite-induced neoplastic transformation of human keratinocytes. Arch Toxicol 87(6):9911000. doi:10.1007/s00204-012-0933-0

Kumasaka MY, Yamanoshita O, Shimizu S, Ohnuma S, Furuta A, Yajima I, Nizam S, Khalequzzaman M, Shekhar HU, Nakajima T, Kato M (2013) Enhanced carcinogenicity by coexposure to arsenic and iron and a novel remediation system for the elements in well drinking water. Arch Toxicol 87(3):439-447. doi:10.1007/s00204-012-0964-6

Liu S, Wang F, Yan L, Zhang L, Song Y, Xi S, Jia J, Sun G (2013) Oxidative stress and MAPK involved into ATF2 expression in immortalized human urothelial cells treated by arsenic. Arch Toxicol 87(6):981-989. doi:10.1007/s00204-013-1058-9

Masoudi M, Saadat M (2008) Minireview: arsenic, GSTO2 ASN142ASP polymorphism, health and treatment. EXCLI J 7:115-118. ISSN: 1611-2156

Méndez-Fernández L, Rodríguez P, Martínez-Madrid M (2015) Sediment toxicity and bioaccumulation assessment in abandoned copper and mercury mining areas of the Nalón River basin (Spain). Arch Environ Contam Toxicol 68(1):107-123. doi:10.1007/s00244-014-0093-8

Pastoret A, Marcos R, Sampayo-Reyes A, Saucedo-Cardenas O, Lozano-Garza GH, Hernandez A (2013) Inhibition of hepatocyte nuclear factor 1 and 4 alpha (HNF1 $\alpha$ and $\mathrm{HNF} 4 \alpha$ ) as a mechanism of arsenic carcinogenesis. Arch Toxicol. doi:10.1007/ s00204-012-0948-6

Selinski S (2012) Genetic variants confer susceptibility to urinary bladder cancer: an updated list of confirmed polymorphisms. EXCLI J 11:743-747

Sinha D, Biswas J, Bishayee A (2013) Nrf2-mediated redox signaling in arsenic carcinogenesis: a review. Arch Toxicol 87(2):383-396. doi:10.1007/s00204-012-0920-5 (Review)

Stern M, Gierse A, Tan S, Bicker G (2014) Human Ntera2 cells as a predictive in vitro test system for developmental neurotoxicity. Arch Toxicol 88(1):127-136. doi:10.1007/s00204-013-1098-1

Stewart JD, Marchan R (2012) Current developments in toxicology. EXCLI J 11:692-702

Tokar EJ, Diwan BA, Waalkes MP (2010) Arsenic exposure in utero and nonepidermal proliferative response in adulthood in Tg.AC mice. Int J Toxicol 29(3):291-296. doi:10.1177/1091581810362804

Tokar EJ, Kojima C, Waalkes MP (2014) Methylarsonous acid causes oxidative DNA damage in cells independent of the ability to biomethylate inorganic arsenic. Arch Toxicol 88(2):249-261. doi:10.1007/s00204-013-1141-2

Waalkes MP, Qu W, Tokar EJ, Kissling GE, Dixon D (2014a) Lung tumors in mice induced by "whole-life" inorganic arsenic exposure at human-relevant doses. Arch Toxicol 88(8):1619-1629. doi:10.1007/s00204-014-1305-8

Waalkes MP, Qu W, Tokar EJ, Kissling GE, Dixon D (2014b) Response to letter to the editor by Cohen et al. (2014a) "Re: Waalkes et al.: Lung tumors in mice induced by "whole-life" inorganic arsenic exposure at human-relevant doses, Arch Toxicol, 2014". Arch Toxicol 88(11):2063-2065. doi:10.1007/ s00204-014-1369-5

Wang HH, Wu MM, Chan MW, Pu YS, Chen CJ, Lee TC (2014) Long-term low-dose exposure of human urothelial cells to sodium arsenite activates lipocalin-2 via promoter hypomethylation. Arch Toxicol 88(8):1549-1559. doi:10.1007/ s00204-014-1214-x

Watanabe T, Hirano S (2013) Metabolism of arsenic and its toxicological relevance. Arch Toxicol 87(6):969-979. doi:10.1007/ s00204-012-0904-5 (Review) 
Weng CY, Chiou SY, Wang L, Kou MC, Wang YJ, Wu MJ (2014) Arsenic trioxide induces unfolded protein response in vascular endothelial cells. Arch Toxicol 88(2):213-226. doi:10.1007/ s00204-013-1101-x

WHO (World Health Organization) (2011a) Seventy-second report of the Joint FAO/WHO Expert Committee on food additives. Evaluation of certain contaminants in food. WHO technical reports series, 959, pp 1-105

WHO (World Health Organization) (2011b) Guidelines for drinking-water quality-4th ed. http://www.who.int/ water_sanitation_health/publications/2011/dwq_guidelines/en/

WHO (World Health Organization) (2011c) Arsenic in Drinking-water. Background document for development of WHO guidelines for drinking-water quality. http://www.who.int/ water_sanitation_health/publications/2011/arsenic/en/

Xu Y, Tokar EJ, Waalkes MP (2014) Arsenic-induced cancer cell phenotype in human breast epithelia is estrogen receptor-independent but involves aromatase activation. Arch Toxicol 88(2):263-274. doi:10.1007/s00204-013-1131-4

Yu M, Xue J, Li Y, Zhang W, Ma D, Liu L, Zhang Z (2013) Resveratrol protects against arsenic trioxide-induced nephrotoxicity by facilitating arsenic metabolism and decreasing oxidative stress. Arch Toxicol 87(6):1025-1035. doi:10.1007/s00204-013-1026-4

Zhou X, Sun X, Mobarak C, Gandolfi AJ, Burchiel SW, Hudson LG, Liu KJ (2014) Differential binding of monomethylarsonous acid compared to arsenite and arsenic trioxide with zinc finger peptides and proteins. Chem Res Toxicol 27(4):690-698. doi: $10.1021 / \mathrm{t} \times 500022 \mathrm{j}$

Zimmer B, Pallocca G, Dreser N, Foerster S, Waldmann T, Westerhout J, Julien S, Krause KH, van Thriel C, Hengstler JG, Sachinidis A, Bosgra S, Leist M (2014) Profiling of drugs and environmental chemicals for functional impairment of neural crest migration in a novel stem cell-based test battery. Arch Toxicol 88(5):1109-1126. doi:10.1007/s00204-014-1231-9 